EDYTA WOLTER

Wydział Nauk Pedagogicznych

Uniwersytet Kardynała Stefana Wyszyńskiego

Warszawa
Forum Pedagogiczne

$2016 / 2$ cz. 2

Wpłynęło: 22.05.2016

Zatwierdzono do druku: 26.10.2016 DOI: $10.21697 /$ fp.2016.2.28

\title{
W TROSCE O ŚWIADOMOŚĆ EKOLOGICZNA SPOŁECZEŃSTWA XXI WIEKU
}

Streszczenie: Celem artykułu jest wyjaśnienie znaczenia kształtowania świadomości ekologicznej społeczeństwa żyjącego w uwarunkowaniach kultury postindustrialnej, społeczeństwa wiedzy - na przykładzie zaleceń Organizacji Narodów Zjednoczonych do spraw Oświaty, Nauki i Kultury (UNESCO), Unii Europejskiej oraz Kościoła katolickiego. Artykuł ma strukturę problemową. Bazę źródłową stanowią źródła drukowane Polskiego Komitetu do spraw UNESCO („Biuletyn Polskiego Komitetu ds. UNESCO”), Komisji Europejskiej oraz dotyczące myśli społecznej Kościoła katolickiego.

Słowa kluczowe: kultura postindustrialna, świadomość ekologiczna, wychowanie ekologiczne, postawy ekologiczne, Polski Komitet do spraw UNESCO, Komisja Europejska, dokumenty Kościoła katolickiego

Celem artykułu jest zaprezentowanie osiągnięć Organizacji Narodów Zjednoczonych do spraw Oświaty, Nauki i Kultury, Unii Europejskiej oraz myśli społecznej Kościoła katolickiego (na celowo wybranych przykładach) w procesie kształtowania świadomości ekologicznej społeczeństwa postindustrialnego/ponowoczesnego społeczeństwa wiedzy w skali globalnej. W związku z tym przeprowadzono analizę dokumentów wymienionych organizacji i instytucji w zakresie treści. W artykule zastosowano strukturę problemową, $\mathrm{z}$ odniesieniami do poszczególnych części dzieła.

\section{Działalność Organizacji Narodów Zjednoczonych do spraw Oświaty, Nauki i Kultury (UNESCO) w zakresie ochrony środowiska}

Organizacja Narodów Zjednoczonych (United Nations) jest międzynarodową organizacją działającą od 1945 roku na rzecz światowego pokoju. Organizację Narodów Zjednoczonych do spraw Oświaty, Nauki i Kultury (United Nations Educational, Scientific and Cultural Organization) założono w 1946 roku w celu zacieśniania międzynarodowej współpracy w obszarze oświaty, nauki i kultury. 
Wśród największych osiągnięć tej wyspecjalizowanej jednostki są działania dotyczące ochrony dziedzictwa kulturowego, materialnego i niematerialnego oraz naturalnego (por. Rottermund 2014, s. 9). W 1946 roku utworzono w Polsce Narodowy Komitet Współpracy z Organizacją Narodów Zjednoczonych dla Spraw Wychowania, Nauki i Kultury, początkowo w Muzeum Narodowym, a od czerwca 1948 roku w Ministerstwie Oświaty. Po zawieszeniu działalności Polski w UNESCO Komitet przestał działać. Wznowienie jego prac nastąpiło w październiku 1954 roku (UNESCO... 2014, s. 16-17). Od 2011 roku przewodniczącym Polskiego Komitetu ds. UNESCO był prof. Andrzej Rottermund (historyk sztuki, dyrektor Zamku Królewskiego w Warszawie) (tamże, s. 77), natomiast w lipcu 2015 roku został nim prof. Jacek Purchla (tamże, s. 80).

W 1948 roku UNESCO powołała Międzynarodową Unię Ochrony Przyrody i Jej Zasobów (IUCN), która obecnie funkcjonuje jako Międzynarodowa Unia Ochrony Przyrody i jest organizacją doradczą UNESCO w procesie tworzenia rezerwatów biosfery (por. tamże, s. 19). W 1958 roku powstał w Polsce Komitet Narodowy Międzynarodowej Unii Ochrony Przyrody i Jej Zasobów. W 1960 roku odbyła się w Warszawie 7. sesja tej organizacji. Profesora Władysława Szafera powołano na stanowisko honorowego prezesa IUCN (tamże, s. 29). W tym samym roku opublikowano Poradnik UNESCO do nauczania przedmiotów przyrodniczych (wydany nakładem Państwowych Zakładów Wydawnictw Szkolnych). Na marginesie można dodać, że ukazał się on również w wielu językach obcych (tamże, s. 35).

26 maja 1969 roku wydano raport sekretarza generalnego ONZ Sithu U Thanta pt. Człowiek i jego środowisko, który przyczynił się do rozwoju prac UNESCO dotyczących środowiska, szczególnie w zakresie oceanografii. Tekst tego raportu umieszczono także w specjalnym numerze „Biuletynu Polskiego Komitetu ds. UNESCO" (tamże, s. 38).

\section{Lista światowego dziedzictwa UNESCO}

Podczas 17. sesji Konferencji Generalnej UNESCO w Paryżu w 1972 roku ogłoszono pierwszy akt normatywny, traktujący łącznie dziedzictwo kulturowe i przyrodnicze - Konwencję w sprawie ochrony światowego dziedzictwa kulturowego i przyrodniczego (tamże, s. 41). Konwencja ta stanowi podstawę wszelkich działań związanych ze światowym dziedzictwem kulturowym i przyrodniczym/naturalnym. Po jej ratyfikowaniu przez dwadzieścia państw weszła w życie w 1975 roku. Polska złożyła dokument ratyfikacyjny w 1976 roku. Obecnie sygnatariuszami Konwencji jest 191 państw (por. Konwencja... 1972, passim).

W dokumencie tym za dobra kulturowe uznano zabytki (dzieła architektury, monumentalnej rzeźby i malarstwa, elementy i budowle o charakterze archeologicznym, napisy, jaskinie i zgrupowania tych elementów o wyjątkowej wartości z punktu widzenia historii, sztuki lub nauki), zespoły budowli oddzielnych lub łącznych (które mają wyjątkową wartość historyczną), miejsca zabytkowe (dzieła 
człowieka lub wspólne dzieła człowieka i przyrody oraz strefy, stanowiska archeologiczne o wyjątkowej wartości historycznej, estetycznej, etnograficznej, antropologicznej) (por. Kryteria... 1972, s. 1). Natomiast dziedzictwo przyrodnicze tworzą: pomniki przyrody (stanowiące formacje fizyczne, biologiczne lub zespoły formacji o wyjątkowej wartości estetycznej, naukowej), formacje geologiczne i fizjograficzne oraz wyznaczone obszary (stanowiące siedliska zagrożonych gatunków zwierząt i roślin o wyjątkowej wartości naukowej lub ochronnej), a także obszary przyrody o wyjątkowej wartości naukowej, ochronnej lub piękna natury (por. tamże, s. 3). Przy czym każde dobro przyrodnicze powinno mieć plan zarządzania z ochroną prawną, instytucjonalną w perspektywie długoterminowej. Granice obiektu mogą pokrywać się z jedną lub kilkoma strefami chronionymi (takimi jak parki narodowe czy rezerwaty biosfery) (por. tamże, s. 4).

W trakcie obchodów 40. rocznicy powstania Konwencji w sprawie ochrony światowego dziedzictwa kulturalnego i naturalnego na 36. posiedzeniu Komitetu Światowego Dziedzictwa UNESCO w Petersburgu 24 czerwca - 6 lipca 2012 roku stwierdzono, że wyzwaniem dla UNESCO jest zapewnienie obiektom ochrony przed katastrofami naturalnymi, szkodliwym wpływem zmian klimatycznych. Przypomniano, że Lista światowego dziedzictwa UNESCO (dane z 2012 roku) liczy 962 obiekty (w tym: 745 kulturalnych, 188 przyrodniczych oraz 20 o charakterze mieszanym), które znajdują się w 157 państwach będących sygnatariuszami Konwencji (por. 36. posiedzenie Komitetu... 2012, s. 47).

Obecnie Listęświatowego dziedzictwa UNESCO tworzy 1031 obiektów położonych w 163 państwach. Są to obiekty kultury (802), przyrodnicze (197) i kulturowo-przyrodnicze, czyli mieszane (32) (Światowe dziedzictwo... 2016, passim). W 1978 roku Komitet Światowego Dziedzictwa wpisał na Listę światowego dziedzictwa UNESCO dwa polskie obiekty: zespół staromiejski w Krakowie i Kopalnię Soli Wieliczka, natomiast w 1979 roku na liście tej umieszczono Puszczę Białowieską (por. UNESCO... 2014, s. 47). Po zakwalifikowaniu również kopalni soli w Bochni - 23 czerwca 2013 roku, nadano im wspólną nazwę Królewskie Kopalnie Soli Wieliczka i Bochnia (por. Piotrowska 2013, s. 46-47). Należy wyjaśnić, że umieszczenie obiektu na Liście światowego dziedzictwa UNESCO stanowi potwierdzenie sprawnego zarządzania unikalnym dobrem kulturalnym lub przyrodniczym światowego dziedzictwa, a także sprzyja jego międzynarodowej promocji (por. tamże, s. 52).

\section{Sieć rezerwatów biosfery}

Podczas 37. sesji Konferencji Generalnej UNESCO w Paryżu 5-2o listopada 2013 roku wśród głównych kierunków działań na najbliższe lata wymieniono: poszerzanie wiedzy i rozwijanie kompetencji w zakresie ochrony i zrównoważonego zarządzania oceanami i obszarami przybrzeżnymi, umacnianie roli nauk ekologicznych i rezerwatów biosfery, zwiększanie wysiłków dla zapewnienia bezpieczeństwa zasobów słodkowodnych oraz oferowanie państwom członkowskim 
narzędzi zarządzania etycznymi, prawnymi, środowiskowymi i społecznymi skutkami wyzwań naukowo-technicznych związanych z rozwojem społeczeństwa, ochroną, promowaniem i przekazywaniem dziedzictwa kultury (por. Założenia programowe... 2013, s. 9-10). Uchwalono wówczas dokument pt. Strategia średnioterminowa UNESCO na lata 2014-2021, w którym określono znaczenie wspierania wysokiej jakości edukacji ustawicznej, kształcenia odpowiedzialnych obywateli globalnego społeczeństwa, tworzenia płaszczyzn współpracy naukowej, politycznej, kulturowej, społecznej dla pokoju, ochrony i promocji dziedzictwa, zrównoważonego rozwoju oraz zapobiegania wykluczeniu społecznemu (por. Ratajski 2013, s. 12).

W celu ochrony biosfery powstał Program UNESCO Człowiek i biosfera (Man and Biosphere $-M A B$ ), w ramach którego stworzono sieć rezerwatów biosfery. Na obszarze Rzeczypospolitej Polskiej działa dziesięć takich rezerwatów, a za jedno z największych osiągnięć porozumienia rządów Polski, Białorusi i Ukrainy uznano utworzenie w 2012 roku Transgranicznego Rezerwatu Biosfery Polesie Zachodnie (por. tamże, s. 16).

Program UNESCO Człowiek i biosfera był przez lata doskonalony. Od 2015 roku globalna sieć obejmuje 651 rezerwatów biosfery (w tym 15 obiektów transgranicznych) w 120 państwach (por. UNESCO... 2014, s. 40). Rezerwaty biosfery funkcjonują na podstawie Ramowego statutu światowej sieci rezerwatów biosfery, który opracowano na konferencji UNESCO w Sewilli w 1995 roku (por. Krzemiński 2013, s. 95). W rezerwacie biosfery ustanowionym przez UNESCO są wyznaczane następujące sfery: centralna (stanowiąca część rdzenną, zapewniająca ochronę różnorodności biologicznej), buforowa (otaczająca obszar centralny, na której jest realizowana działalność naukowo-badawcza, gospodarcza oraz w zakresie edukacji ekologicznej, rekreacji, turystyki ekologicznej), przejściowa (w której są realizowane funkcje zrównoważonego rozwoju w zakresie np. gospodarki leśnej, rolnej, rybackiej itp.) (por. tamże, s. 96). Według danych Polskiego Komitetu Narodowego UNESCO-MAB na obszarze Polski są następujące rezerwaty biosfery: Babia Góra, Białowieża, Jezioro Łuknajno, Słowiński, Karpaty Wschodnie, Tatry, Karkonosze, Puszcza Kampinoska, Polesie Zachodnie, Bory Tucholskie (tamże).

Głównym czynnikiem regulującym procesy krążenia wody i pierwiastków (węgiel, fosfor, azot) w biogeosferze są ekosystemy. Człowiek stał się najważniejszym czynnikiem ewolucji biogeochemicznej na Ziemi, jego działalność wpływa bowiem na degradację systemu wspierającego życie oraz modyfikację cyklu wodnego w różnych typach ekosystemów. W XXI wieku stwierdzono, że ponad 70\% ekosystemów zostało zmienionych przez działalność ludzi z powodu wylesiania, urbanizacji, budowy szlaków komunikacyjnych. Degradacja struktur ekosystemowych w powiązaniu z intensywną emisją zanieczyszczeń do atmosfery, wód śródlądowych oraz przybrzeżnych spowodowała modyfikację procesów ekologicznych. Ważne jest więc zrozumienie wzajemnych oddziaływań pomiędzy procesami ekologicznymi i hydrologicznymi ukształtowanymi w procesie ewolucji biologicznej, a także integrowanie badań naukowych, procesów zrównoważonego kształtowania kultury oraz edukacyjnych aspektów rozwoju człowieka (por. Zalewski 2012, s. 53-55). 


\section{Sieć Szkół Stowarzyszonych UNESCO}

$\mathrm{W}$ trosce o zachowanie dynamicznej równowagi złożonej z sieci życia zależnej od Słońca i, co się z tym wiąże, zapewnienie prawidłowego krążenia materii należy prowadzić zrównoważony dialog ze środowiskiem i zrozumieć przyrodę. Według Anny Kalinowskiej „zrównoważony rozwój nie jest jedną z możliwości. To jedyna droga, która pozwoli całej ludzkości wieść godne życie na tej planecie, jedynej jaką mamy" (Kalinowska 2013, s. 79-84). Zrównoważony rozwój w rozumieniu UNESCO opiera się na czterech następujących filarach: środowisku, społeczeństwie, gospodarce, kulturze (por. Machinko-Nagrabecka 2013, s. 85). W związku z tym od 1963 roku tworzona jest Sieć Szkół Stowarzyszonych UNESCO (ASPnet), którą obecnie tworzy prawie dziesięć tysięcy instytucji edukacyjnych w 180 państwach (por. Wychowywać w dialogu... 2013, s. 90). Systematycznie wzrasta również liczba Szkół Stowarzyszonych UNESCO w Polsce (podstawowych i średnich) ${ }^{1}$. Promują one ideę globalnego obywatelstwa na poziomie krajowym, regionalnym, międzynarodowym; realizują projekty w następujących obszarach: pokój i prawa człowieka, nauczanie międzykulturowe, edukacja dla zrównoważonego rozwoju (w tym: obniżenie ryzyka katastrof, zmiany klimatyczne, bioróżnorodność) oraz rola ONZ w rozwiązywaniu problemów światowych (por. Sieć ASPnet... 2013, s. 93).

\section{Polityka Unii Europejskiej w trosce o świadomość ekologiczną społeczeństwa globalnego}

Rober Schuman - uznany za jednego z „duchowych ojców” Unii Europejskiej, twórca projektu integracji europejskiej (zob. Założyciele UE 2013, s. 19) - podczas przemówienia 9 maja 1950 roku wygłosił następującą deklarację: „Europa nie powstanie od razu ani według $\mathrm{z}$ góry ustalonego planu: będzie powstawała poprzez konkretne realizacje, tworząc najpierw rzeczywistą solidarność" (Fontaine 2014, s. 37). W procesach decyzyjnych na poziomie Unii Europejskiej udział biorą następujące instytucje: Parlament Europejski (reprezentuje obywateli Unii Europejskiej), Rada Europejska (którą tworzą szefowie rządów państw członkowskich UE)², Rada Unii Europejskiej (reprezentuje rządy państw członkowskich), Komisja Europejska

1 Według danych z 1998 roku 89 szkół średnich i 11 szkół podstawowych (por. UNESCO i Polska 2014, s. 64).

2 Radę Europejską utworzono w grudniu 1974 roku. Po raz pierwszy obradowała w Dublinie w marcu 1975 roku. W grudniu 1989 w Strasburgu Rada Europejska ustaliła, że w grudniu następnego roku rozpocznie się konferencja międzyrządowa w sprawie unii gospodarczej i walutowej. W kwietniu 1990 roku Rada Europejska w Dublinie zaczęła przygotowywać konferencję międzyrządową w sprawie unii politycznej. Traktat z Maastricht (podpisany 7 lutego $1992 \mathrm{roku}$ ) wszedł w życie 1 listopada 1993 roku. Na jego mocy powstała Unia Europejska, której podstawą był poszerzony filar wspólnotowy (przewidujący zwłaszcza wprowadzenie unii gospodarczej i walutowej) i dwa nowe filary: wspólna polityka zagraniczna i bezpieczeństwa oraz współpraca 
(reprezentuje Unię Europejską jako całość) (por. Zrozumieć politykę... 2014, s. 5). Od 1 grudnia 2014 roku Radzie Europejskiej przewodniczy Donald Tusk (tamże, s. 13), Jean-Claude Juncker stoi na czele Komisji Europejskiej (tamże, s. 19), a Federica Mogherini jest szefową polityki zagranicznej Unii Europejskiej (koordynuje jej działania zewnętrzne) (tamże, s. 21). Parlamenty narodowe kontrolują stosowanie zasady pomocniczości (otrzymują wszystkie nowe wnioski ustawodawcze i mogą wydawać uzasadnione opinie) (por. tamże, s. 23). Natomiast Trybunał Sprawiedliwości jest uprawniony do rozstrzygania w sporach między państwami członkowskimi, instytucjami Unii Europejskiej, przedsiębiorstwami oraz osobami fizycznymi (por. tamże, s. 24).

Jednym z priorytetowych celów polityki Unii Europejskiej jest międzynarodowa i holistycznie ujęta ochrona środowiska (od suszy i powodzi po zanieczyszczenie powietrza oraz zagrożenia dla europejskiego środowiska naturalnego i bioróżnorodności) (por. Środowisko... 2013, s. 3). Celem polityki UE dotyczącej środowiska jest zachowanie równowagi między potrzebami rozwoju i wykorzystywania dóbr naturalnych a ochroną środowiska także dla przyszłych pokoleń (por. tamże, s. 8). Europejska Agencja Środowiska (z siedzibą w Kopenhadze) gromadzi dane krajowe oraz opracowuje wskaźniki i sprawozdania dotyczące stanu środowiska (por. tamże, s. 5). Ważnym elementem polityki Unii Europejskiej jest popularyzacja wiedzy o środowisku naturalnym, a także organizowanie różnorodnych konkursów. Egzemplifikację stanowi konkurs na Zieloną Stolicę Europy - w którym wyróżniana jest działalność na rzecz ochrony przyrody i zapewnienia wysokich standardów ochrony środowiska. Wśród laureatów tego konkursu są następujące miasta: Sztokholm (2010), Hamburg (2011), Vitoria-Gasteiz (2012), Nantes (2013), Kopenhaga (2014), Bristol (2015) (por. tamże, s. 11).

W 2013 roku został przyjęty przez Parlament Europejski i Radę Unii Europejskiej Siódmy ogólny unijny program działań w zakresie środowiska naturalnego do $2020 \mathrm{r}$., $\mathrm{w}$ celu wzmocnienia działań na rzecz ochrony środowiska, zdrowia, dobrostanu społecznego oraz stymulowania rozwoju, innowacji opartych na zasobooszczędnej, niskoemisyjnej gospodarce, uwzględniającej naturalne ograniczenia Ziemi (Dobra jakość życia... b.r.w., s. 1). Program implikuje następujące cele priorytetowe, którymi Unia Europejska musi się zająć, by zrealizować je do 2020 roku:

- ochrona, zachowanie i poprawa kapitału przyrodniczego/naturalnego Unii;

- przekształcenie Unii w zasobooszczędną, zieloną i konkurencyjną gospodarkę niskoemisyjną;

- ochrona obywateli Unii przed związanymi ze środowiskiem problemami i zagrożeniami dla ich zdrowia i dobrostanu;

- maksymalizacja korzyści płynących z prawodawstwa Unii w zakresie środowiska poprzez lepsze jego wdrażanie;

w zakresie wymiaru sprawiedliwości i spraw wewnętrznych (por. Rada Europejska... 2012, s. 8-11). 
- doskonalenie wiedzy i bazy dowodowej unijnej polityki w zakresie środowiska;

- zabezpieczenie inwestycji na rzecz polityki w zakresie środowiska i klimatu oraz uwzględnienie kosztów ekologicznych wszelkich rodzajów działalności społecznej;

- lepsze uwzględnianie problematyki środowiska i większa spójność polityki;

- wspieranie zrównoważonego rozwoju miast Unii;

- zwiększenie efektywności Unii w podejmowaniu międzynarodowych wyzwań związanych ze środowiskiem i klimatem (tamże, s. 2).

W lutym 2015 roku Komisja Europejska przedstawiła strategię ustanowienia stabilnej unii energetycznej z perspektywiczną polityką dotyczącą zmian klimatu, która koncentruje się m.in. na redukcji emisji gazów cieplarnianych o co najmniej 40\% do 2030 roku (co oznacza konieczność inwestycji w rozwój odnawialnych źródeł energii) (por. Stabilna unia... 2015, s. 6). Przewodniczący Komisji Europejskiej Jean-Claude Juncker podczas przemówienia o stanie Unii w 2015 roku w Parlamencie Europejskim w Strasburgu (9 września 2015 r.) stwierdził, że Unia Europejska i państwa członkowskie odegrały ważną rolę, pośrednicząc w historycznym, bo pierwszym $w$ historii globalnym i prawnie wiążącym porozumieniu w sprawie klimatu, które zawarło w Paryżu 195 państw. Przyjęto wtedy ogólnoświatowy plan działań, chroniących przed groźbą zmiany klimatu poprzez ograniczenie globalnego ocieplenia do wartości znacznie poniżej $2^{\circ} \mathrm{C}$. Porozumienie to ukierunkowuje rozwój gospodarki światowej na produkcję czystej energii i stanowi osiągnięcie Unii Europejskiej. Juncker zaakcentował, że Europa od dawna pełni rolę lidera w działaniach na rzecz klimatu (Juncker 2016, s. 5).

Unijna polityka klimatyczna ma ogromne znaczenie, ponieważ klimat na Ziemi ulega ustawicznym przemianom, a średnia temperatura na świecie jest coraz wyższa. W wyniku działalności człowieka rośnie poziom emisji gazów cieplarnianych, które przepuszczają do atmosfery ziemskiej promieniowanie słoneczne, ale nie wypuszczają z niej promieniowania cieplnego. Wzrost temperatury powoduje na świecie zjawiska o niespotykanej dotychczas skali, takie jak np. topnienie lodowców, podnoszenie się poziomu wody $\mathrm{w}$ morzach $\mathrm{i}$ oceanach, powodzie $\mathrm{w}$ regionach, które w przeszłości nie doświadczały ekstremalnych warunków pogodowych, fale upałów, które spowodowały w Europie dziesiątki tysięcy przedwczesnych zgonów (por. Dlaczego potrzebujemy unijnej polityki... 2014, s. 3-4). Ponieważ zmiany klimatu wymagają holistycznych działań na poziomie międzynarodowym, określono następujące zadania Komisji Europejskiej w walce ze zmianami klimatu:

- opracowywanie i realizowanie unijnych strategii politycznych i działań w dziedzinie klimatu;

- reprezentowanie Unii Europejskiej podczas międzynarodowych negocjacji wspólnie z aktualną prezydencją Rady UE;

- zarządzanie unijnym systemem handlu uprawnieniami do emisji (ETS);

- nadzorowanie realizacji przez państwa członkowskie Unii Europejskiej celów redukcji emisji w sektorach nieobjętych systemem ETS; 
- promowanie przejścia na gospodarkę niskowęglową, wykorzystującą czyste technologie;

- realizacja unijnej strategii dostosowania się do zmiany klimatu oraz wspieranie działań państw członkowskich w tym zakresie;

- zarządzanie budżetem Unii Europejskiej, którego 20\% zarezerwowano na wspieranie działań dotyczących klimatu (tamże, s. 6).

Należy podkreślić, że w walce ze zmianami klimatycznymi wielką pomocą służą lasy, ponieważ odgrywają najważniejszą rolę w procesie wychwytywania dwutlenku węgla $\mathrm{z}$ atmosfery i magazynowania go $\mathrm{w}$ glebie i biomasie, co przyczynia się do stabilizacji klimatu. Poza tym są źródłem drewna (które jest odnawialnym i przyjaznym dla środowiska zasobem/surowcem) oraz biomasy do produkcji energii (por. Lasy Europy... 2010, s. 2). Ponieważ ludzie w alarmującym tempie wycinają lasy, na całym świecie są podejmowane działania w celu zachowania obszarów leśnych oraz zapobieżenia sprzedaży nielegalnie ściętych drzew. Zgodnie z unijnymi aktami normatywnymi należy śledzić drogę surowca (od lasu do składu drewna), bo to gwarantuje, że do Unii Europejskiej jest importowane jedynie legalnie pozyskane drewno (por. Niszczymy... 2015, s. 22). Redukcji zmian klimatycznych pomocą służą także nowe technologie, zmniejszające emisję zanieczyszczeń i poziom hałasu. Przykład stanowią te dotyczące ruchu lotniczego - zastosowanie naturalnych skrzydeł laminarnych oraz innowacyjnego rodzaju silnika samolotowego (dwuprzepływowego) (por. W jaki sposób UE... 2014, s. 7).

Do najważniejszych celów unijnej polityki w dziedzinie zdrowia zaliczono: zapobieganie chorobom, promowanie zdrowego stylu życia, dbanie o dobry stan psychiki, ochronę ludności przed poważnymi zagrożeniami dla zdrowia mającymi wymiar międzynarodowy, lepszy dostęp do opieki zdrowotnej, rozpowszechnianie informacji na temat zdrowia i wspieranie edukacji zdrowotnej, zapewnianie pacjentom bezpieczeństwa, wspieranie dynamicznych systemów opieki zdrowotnej i nowych technologii, ustanawianie wysokich norm jakości i bezpieczeństwa w odniesieniu do narządów i innych substancji pochodzenia ludzkiego, zapewnianie bezpiecznych i skutecznych produktów leczniczych i wyrobów medycznych wysokiej jakości (Zdrowie publiczne... 2013, s. 3). W myśl programu działań w dziedzinie zdrowia publicznego na lata 2014-2020 Unia Europejska podkreśla znaczenie zdrowia dla wydajności i konkurencyjności gospodarki w aspekcie indywidualnym - w obszarze dobrej jakości życia. Propaguje też: zdrowy styl życia i profilaktykę zdrowotną, ochronę obywateli przed zagrożeniami o wymiarze międzynarodowym, innowacyjne i zrównoważone systemy opieki zdrowotnej (bezpieczną opiekę zdrowotną wyższej jakości), surowe przepisy dotyczące wyrobów medycznych (por. tamże, s. 15).

W myśl zaleceń unijnej polityki dotyczącej bezpieczeństwa żywności ogromne znaczenie ma ochrona zdrowia ludzi, zwierząt i roślin na każdym etapie procesu produkcji żywności (po konsumpcję). Polityka unijna ochrania zdrowie przez: zapobieganie skażeniu żywności, promowanie jej higieny, rozpowszechnianie 
informacji o żywności, zdrowiu roślin oraz na temat dobrostanu zwierząt. UE promuje żywność wysokiej jakości oraz tradycyjną, a także zaleca redukowanie marnotrawstwa żywności (por. Dlaczego potrzebujemy unijnej polityki... 2014, s. $3-4,15)$.

Wspólna polityka rolna (WPR) dotyczy wszystkich państw członkowskich Unii Europejskiej. Jest zarządzana i finansowana ze środków pochodzących z rocznego budżetu Unii Europejskiej. Wysoka jakość żywności odzwierciedla znakomite tradycje kulinarne. Rolnictwo ekologiczne podąża za naturalnym cyklem życia roślin i zwierząt, a metody produkcji ekologicznej muszą być zgodne z przepisami prawodawstwa Unii Europejskiej (od wyprodukowania żywności do nabycia jej przez konsumenta) (por. Wspólna polityka rolna... 2012, s. 3, 13). Warto dodać, że w celu ochrony konsumentów i zdrowia publicznego w 2002 roku utworzono Europejski Urząd ds. Bezpieczeństwa Żywności (EFSA) (Fontaine 2014, s. 23).

Bardzo ważnym problemem jest także jakość wody pitnej, która w kranach około $75 \%$ Europejczyków pochodzi z wód gruntowych znajdujących się pod ziemią, $\mathrm{w}$ glebie i skałach oraz w przestrzeniach zwanych warstwami wodonośnymi. Wśród substancji zanieczyszczających wodę są: czynniki chorobotwórcze (np. bakterie, wirusy), chemikalia organiczne (np. detergenty, smary, rozpuszczalniki) i nieorganiczne (np. nawozy zawierające azotany i fosforany, metale ciężkie) oraz śmieci.

Niezbędna do życia woda (słodka, pitna) stanowi zaledwie ok. 2,5\% wszystkich zasobów wodnych na Ziemi (por. Czy chcielibyście... 2012, s. 4-6). Unia Europejska podejmuje więc działania w celu zabezpieczania wody pitnej (zgodnie z zaleceniami Światowej Organizacji Zdrowia) oraz chroni zdrowie obywateli przed zagrożeniem wynikającym z nieoczyszczania ścieków (wody kanalizacyjnej, zużytej wody z gospodarstw i ścieków przemysłowych), głównie poprzez wprowadzenie dyrektywy dotyczącej oczyszczania ścieków komunalnych UE, która zobowiązuje do działań na rzecz ograniczenia zanieczyszczeń środowiska (por. tamże, s. 26).

W trosce o świadomość ekologiczną obywateli Unii Europejskiej rozwija się również turystyka, bowiem „piękno natury i różnorodność kulturowa Europy sprawiają, że w skali świata jest ona głównym celem podróży turystycznych" (Turystyka w Unii Europejskiej... 2014, s. 1). Na obszarze Unii działają Europejskie Modelowe Ośrodki Turystyczne (EDEN), które dążą do rozwijania turystyki zrównoważonej pod względem społecznym, kulturalnym, środowiskowym. Umożliwiają odkrywanie dziedzictwa kulturalnego, a także malowniczych pejzaży oraz obszarów chronionych (por. tamże, s. 6). Zrównoważona turystyka ma związek z ochroną dziedzictwa przyrodniczego i kulturowego, ogranicza niekorzystne skutki dla środowiska, a także sprzyja realizowaniu postawy szacunku dla społeczności lokalnej (por. tamże, s. 10).

Ponadmaterialną wartość europejskiej przyrody można odkrywać także dzięki programowi „Natura 2000”, który umożliwia wszystkim państwom członkowskim Unii Europejskiej zachowanie dziedzictwa przyrodniczego oraz współpracę w zakresie ochrony rzadkich gatunków i siedlisk na całym obszarze ich występowania 
w Europie (dzięki tworzeniu ekologicznej sieci obszarów). Program „Natura 200o” ochrania zdrowe ekosystemy, dzikie ptactwo oraz zagrożone wyginięciem gatunki roślin i zwierząt (a także ich siedliska) (Środowisko... 2013, s. 10). Może pomóc w poznawaniu różnych regionów w Europie, zdobywaniu wiedzy na temat dzikiej przyrody, jej zagrożeń i sposobów zapobiegania im, a także poznawaniu krajobrazu jako swoistej naturalnej „zielonej szkoły” (por. Natura 200o... 2006, s. 1-2).

\section{Dezyderaty Kościoła katolickiego w obszarze społecznej świadomości ekologicznej}

W dokumentach Kościoła katolickiego z 2. połowy XX i z XXI wieku zarysowano linię rozwojową dotyczącą problematyki kształtowania świadomości ekologicznej, ochrony środowiska życia w skali globalnej. Egzemplifikację stanowią encykliki: św. Jana XXII pt. Pacem in terris, Pawła VI pt. Populorum progressio, św. Jana Pawła II pt. Redemptor hominis, Benedykta XVI pt. Caritas in veritate. O integralnym rozwoju ludzkim w miłości i prawdzie, a także Franciszka pt. Laudato si. W trosce o wspólny dom.

W niniejszym artykule uwagę skupiono na analizie najnowszej encykliki „ekologicznej” papieża Franciszka pt. Laudato si'. W trosce o wspólny dom, którą ogłoszono 18 czerwca 2015 roku. Ojciec Święty napisał w niej, że chociaż globalny ruch ekologiczny ma bogatą tradycję, to nadal „wyzwanie ochrony naszego wspólnego domu obejmuje troskę o zjednoczenie całej rodziny ludzkiej w dążeniu do zrównoważonego i zintegrowanego rozwoju" (Franciszek 2015, s. 12). W swoich rozważaniach na temat znaczenia ponadmaterialnej wartości przyrody odwołał się do intuicji ekologicznej św. Franciszka z Asyżu, podkreślił, że jego postawa ekologiczna powinna być wzorem troski o środowisko społeczno-przyrodnicze. Stwierdził, że kultury ekologicznej nie można sprowadzać do jednostronnych odpowiedzi na problemy dotyczące degradacji środowiska przyrodniczego, lecz powinna stać się ona holistycznym programem edukacyjnym, stylem życia i rozwoju duchowego, które wyrażają sprzeciw wobec ekspansji paradygmatu technologicznego (por. tamże, s. 74), wypaczonego antropocentryzmu (tamże, s. 78).

Rozważając znaczenie świadomości ekologicznej, papież Franciszek zacytował następujący fragment $\mathrm{z}$ encykliki Caritas in veritate. O integralnym rozwoju ludzkim w miłości i prawdzie papieża Benedykta XVI (z 29 czerwca 2009 roku): „każde naruszenie solidarności i przyjaźni obywatelskiej powoduje szkody ekologiczne" (tamże, s. 93). Natomiast w nawiązaniu do Deklaracji $z$ Rio $w$ sprawie środowiska i rozwoju (z 14 czerwca 1992 roku) Franciszek przypomniał, że aby osiągnąć zrównoważony rozwój, ochrona środowiska powinna stanowić nierozłączną część procesu rozwoju, nie może być rozpatrywana oddzielnie (tamże, s. 92).

$\mathrm{W}$ trosce o ochronę środowiska społeczno-przyrodniczego zaakcentował ogromne znaczenie globalnego ruchu ekologicznego, który wyraża się w wielu działaniach na arenie międzynarodowej: od wspomnianego już raportu Człowiek 
i jego środowisko (1969), a także I Światowego Kongresu Ziemi w Sztokholmie (1972) pt. Środowisko człowieka/Tylko jedna Ziemia, po światowy Szczyt Ziemi w Rio de Janeiro (1992) pt. Środowisko i rozwój (tamże, s. 107). W analizowanej encyklice napisał, że w trosce o wspólny dom (siedlisko życia) należy podjąć wyzwania: kulturowe, duchowe, edukacyjne na rzecz „obywatelskiego zaangażowania ekologicznego" (tamże, s. 132), a także wyzwanie integralnego osobistego nawrócenia (na wzór św. Franciszka z Asyżu) (tamże, s. 136, 138) w procesie kształtowania postawy „radosnej wstrzemięźliwości” i pokory (tamże, s. 140), budowania „cywilizacji miłości” (tamże, s. 143), pokojowego współistnienia. Słusznie podkreślił, że „każda przemiana wymaga motywacji oraz procesu edukacyjnego" (tamże, s. 14).

\section{Zakończenie}

$\mathrm{Na}$ podstawie analizy treściowej celowo wybranych dokumentów drukowanych dotyczących działalności Organizacji Narodów Zjednoczonych do spraw Oświaty, Nauki i Kultury (UNESCO), Unii Europejskiej oraz myśli społecznej Kościoła katolickiego stwierdzono, że wymienione organizacje i instytucje są bardzo zaangażowane w proces kształtowania świadomości ekologicznej społeczeństwa w skali globalnej. UNESCO jako wyspecjalizowana organizacja ONZ ma liczne osiągnięcia na polu promowania międzynarodowej współpracy na rzecz ochrony środowiska przyrodniczego. W tym celu jest tworzona Lista światowego dziedzictwa UNESCO, globalna sieć rezerwatów biosfery (w tym transgranicznych). Są opracowywane strategie UNESCO zalecające tworzenie płaszczyzn współpracy na rzecz ochrony dziedzictwa przyrodniczego (aktualna dotyczy cezury 2014-2021). Na całym świecie systematycznie wzrasta również Sieć Szkół Stowarzyszonych UNESCO, w których realizowane są projekty dotyczące m.in. edukacji dla zrównoważonego rozwoju.

Unia Europejska prowadzi także politykę związaną z troską o świadomość ekologiczną społeczeństwa globalnego. Jako priorytetową uznaje ochronę środowiska. $\mathrm{W}$ związku z tym popularyzuje wiedzę o środowisku przyrody, realizuje unijny program działań w zakresie ochrony środowiska przyrodniczego, zaleca tworzenie i wdrażanie innowacji dotyczących niskoemisyjnych rozwiązań gospodarczych (redukujących zanieczyszczenie środowiska i zmiany klimatu), ochrania ekosystemy w ramach programu „Natura 200o”, promuje zdrowy styl życia, zdrową żywność, turystykę ekologiczną, organizuje konkurs na Zieloną Stolicę Europy.

W trosce o świadomość ekologiczną społeczeństwa w skali globalnej swoistą syntonię w obszarze działań ideacyjnych współtworzy również myśl społeczna Kościoła katolickiego, zwłaszcza wyrażona w dziełach Benedykta XVI pt. Caritas in veritate. O integralnym rozwoju ludzkim $w$ miłości i prawdzie (rozdział IV) oraz Franciszka pt. Laudato si. W trosce o wspólny dom. W dokumentach tych podkreślono znaczenie szerzenia wiedzy o środowisku oraz kształtowania postaw ekologicznej wrażliwości na wszystkie problemy dotyczące środowiska społeczno-przyrodniczego. Zalecono edukację ekologiczną, rozwijanie postaw ekologicznych 
na fundamencie prawdy, dobra, piękna oraz wartości ekologicznych, takich jak np. szacunek dla życia, odpowiedzialność za środowisko, powściągliwość życia (bez marnotrawstwa dóbr naturalnych, przyrodniczych), co stanowi znaczny wkład w synergię holistycznie ujętych działań w trosce o świadomość ekologiczną społeczeństwa ponowoczesnego.

\section{Bibliografia}

36. posiedzenie Komitetu Światowego Dziedzictwa. 4o. rocznica Konwencji w sprawie ochrony światowego dziedzictwa kulturalnego i naturalnego (2012). „Biuletyn Polskiego Komitetu ds. UNESCO".

Czy chcielibyście pić wodę ze ścieków? Broszura na temat wody przeznaczona dla młodzieży (2012). Luksemburg: Urząd Publikacji Unii Europejskiej.

Dlaczego potrzebujemy unijnej polityki bezpieczeństwa żywności (2014). W: Bezpieczeństwo żywności. „Od pola do stołu” - bezpieczna i zdrowa żywność dla każdego. Luksemburg: Urząd Publikacji Unii Europejskiej.

Dlaczego potrzebujemy unijnej polityki klimatycznej (2014). W: Działania w dziedzinie klimatu. Jak dbać o klimat i środowisko. Luksemburg: Urząd Publikacji Unii Europejskiej.

Dobra jakość życia $z$ uwzględnieniem ograniczeń naszej planety. Siódmy ogólny unijny program działań $w$ zakresie środowiska naturalnego do 2020 r. (b.r.w.). Luksemburg: Komisja Europejska.

Educating in dialogue with the environment. Conference on the occasion of the 6oth anniversary of the UNESCO Associated Schools Project Network (ASPnet) (2013). „Polish National Commission for UNESCO Review Bulletin”.

Fontaine P. (2014). Europa w 12 lekcjach. Luksemburg: Urząd Publikacji Unii Europejskiej.

Franciszek (2015). Encyklika Laudato si'. W trosce o wspólny dom. Kraków: Wydawnictwo M.

Juncker J.-C. (2016). Wprowadzenie. W: UE w 2015 r. Najważniejsze wydarzenia. Luksemburg: Urząd Publikacji Unii Europejskiej.

Kalinowska A. (2013). Czy człowiek współczesny zdolny jest do dialogu ze środowiskiem? „Biuletyn Polskiego Komitetu ds. UNESCO”.

Konwencja. W: Polski Komitet ds. UNESCO, dostępny na: www.unesco.pl/no_cache/kultura/dziedzictwo-kulturowe (otwarty 2.05.2016).

Kryteria wpisu na Listę Światowego Dziedzictwa, dostępny na: www.unesco.pl/ no_cache/kultura/dziedzictwo-kulturowe (otwarty 3.05.2016).

Krzemiński Z. (2013). Udział Polski w Światowej Sieci Rezerwatów Biosfery. „Biuletyn Polskiego Komitetu ds. UNESCO".

Lasy Europy. Stwarzanie warunków do życia (2010). Luksemburg: Unia Europejska Urząd Publikacji. 
Machinko-Nagrabecka M. (2013). Jak uczyć o zrównoważonym rozwoju? „Biuletyn Polskiego Komitetu ds. UNESCO”.

Natura 200o. Odkryj europejska przyrode (2006). Luksemburg: Urząd Publikacji Komisji Europejskiej.

Niszczymy więcej niż tylko drzewa (2015). W: Nasza planeta - nasza przyszłość. Luksemburg: Urząd Publikacji Unii Europejskiej.

Piotrowska K. (2013). Królewskie kopalnie soli w Wieliczce i Bochni na Liście Światowego Dziedzictwa UNESCO. „Biuletyn Polskiego Komitetu ds. UNESCO”.

Rada Europejska. Pięćdziesiąt lat spotkań na szczycie (2012). Luksemburg: Urząd Publikacji Unii Europejskiej, s. 8-11.

Ratajski S. (2013). Czym zajmowat się Polski Komitet do spraw UNESCO w 2013 roku. „Biuletyn Polskiego Komitetu ds. UNESCO”.

Rottermund A. (2014). UNESCO - misja wciąż aktualna. „Biuletyn Polskiego Komitetu ds. UNESCO".

Sieć ASPnet dla globalnego obywatelstwa. Międzynarodowe Forum w Suwon (2013). „Biuletyn Polskiego Komitetu ds. UNESCO”.

Stabilna unia energetyczna $z$ perspektywiczna polityka $w$ kwestii zmiany klimatu (2015). W: Dziesięć priorytetów dla Europy. Luksemburg: Urząd Publikacji Unii Europejskiej.

Środowisko. Zdrowe i zrównoważone środowisko naturalne dla przyszłych pokoleń (2013). Luksemburg: Urząd Publikacji Unii Europejskiej.

Światowe dziedzictwo. W: Polski Komitet ds. UNESCO, dostępny na: www.unesco. $\mathrm{pl} / \mathrm{kultura} / \mathrm{dziedzictwo-kulturowe} \mathrm{(otwarty} \mathrm{2.05.2016).}$

Turystyka w Unii Europejskiej. Czy jesteś gotowy na Europę? (2014). Luksemburg: Urząd Publikacji Unii Europejskiej.

UNESCO i Polska (2014). „Biuletyn Polskiego Komitetu ds. UNESCO”.

UNESCO Programme priorities for the coming years (2013). „Polish National Commission for UNESCO Review Bulletin".

W jaki sposób UE wspiera badania naukowe i innowacje (2014). W: Badania naukowe i innowacje. Przesuwanie granic ludzkiego poznania i poprawa jakości życia. Luksemburg: Urząd Publikacji Unii Europejskiej.

Word Heritage Committee Session in St. Petersburg (2012). „Polish National Commission for UNESCO Review Bulletin".

Wspólna polityka rolna. Partnerstwo Europy i rolników (2012). Luksemburg: Urząd Publikacji Unii Europejskiej.

Wychowywać w dialogu ze środowiskiem. Konferencja z okazji 6o-lecia Sieci Szkół Stowarzyszonych UNESCO (2013). „Biuletyn Polskiego Komitetu ds. UNESCO”.

Zalewski M. (2012). Ekohydrologia: nauka integrująca wiedzę o procesach środowiskowych. „Biuletyn Polskiego Komitetu ds. UNESCO”.

Założenia programowe UNESCO na najbliższe lata (2013). „Biuletyn Polskiego Komitetu ds. UNESCO”.

Założyciele UE (2013). Luksemburg: Urząd Publikacji Unii Europejskiej. 
Zdrowie publiczne. W trosce o zdrowie wszystkich obywateli UE (2013). Luksemburg: Urząd Publikacji Unii Europejskiej.

Zrozumieć politykę Unii Europejskiej. Jak działa Unia Europejska. Przewodnik po instytucjach europejskich (2014). Luksemburg: Urząd Publikacji Unii Europejskiej.

\title{
TAKING CARE OF THE ECOLOGICAL AWARENESS OF THE $21^{\text {ST }}$ CENTURY SOCIETY
}

\begin{abstract}
The aim of the article is to elaborate on the meaning of developing the ecological awareness in a society living in the post-industrial, knowledge-focused culture - based on the example of the recommendations of the United Nations Educational, Scientific and Cultural Organization (UNESCO), the European Union and the Catholic Church. The article has got a problem-based structure. The source basis is composed of printed sources of: the Polish Committee for UNESCO („Biuletyn Polskiego Komitetu ds. UNESCO”), the European Commission and the social thought of the Catholic Church.
\end{abstract}

Keywords: post-industrial culture, ecological awareness, ecological upbringing, ecological foundations, Polish Committee for UNESCO, European Commission, documents of the Catholic Church

Edyta Wolter - doktor habilitowana, pedagog - historyk edukacji, profesor nadzwyczajna w Katedrze Historii Wychowania i Dziejów Oświaty na Wydziale Nauk Pedagogicznych Uniwersytetu Kardynała Stefana Wyszyńskiego w Warszawie. Autorka 165 publikacji naukowych, w tym czterech książek autorskich. Zainteresowania naukowe, główne kierunki badań: kulturowe uwarunkowania edukacji ekologicznej w Polsce, pedagogiczne aspekty zrównoważonego rozwoju w środowisku społeczno-przyrodniczym, pedagogiczne implikacje ekologii człowieka, pedagogika ekologiczna, historyczne aspekty edukacji ekologicznej, edukacja ekologiczna w II Rzeczypospolitej, edukacja ekologiczna dzieci. Adres do korespondencji: Wydział Nauk Pedagogicznych UKSW, ul. Wóycickiego 1/3, budynek nr 15, o1-938 Warszawa. Adres e-mail: e.wolter@uksw.edu.pl. 